\title{
Impact of chitosan-beeswax edible coatings on the quality of fresh strawberries (Fragaria ananassa cv Camarosa) under commercial storage conditions
}

\author{
Elena Velickova ${ }^{\mathrm{a}, *}$, Eleonora Winkelhausen ${ }^{\mathrm{a}}$, Slobodanka Kuzmanova ${ }^{\mathrm{a}}$, Vitor D. Alves ${ }^{\mathrm{b}}$, \\ Margarida Moldão-Martins ${ }^{\text {b }}$ \\ ${ }^{a}$ Department of Food Technology and Biotechnology, Faculty of Technology and Metallurgy, University SS. Cyril and Methodius, Rudjer Boskovic 16, 1000 Skopje, Macedonia \\ ${ }^{\mathrm{b}}$ CEER - Biosystems Engineering, Instituto Superior de Agronomia, Universidade Técnica de Lisboa, Tapada da Ajuda, 1349-017 Lisboa, Portugal
}

\section{A R T I C L E I N F O}

\section{Article history:}

Received 17 September 2012

Received in revised form

30 December 2012

Accepted 4 February 2013

\section{Keywords:}

Strawberry

Chitosan coating

Beeswax

Shelf-life quality

Sensory acceptance

\begin{abstract}
A B S T R A C T
Chitosan-based edible coatings were used to prolong the shelf-life of strawberries stored at $20{ }^{\circ} \mathrm{C}$ and 35 $-40 \%$ RH. Strawberries were coated with four different coating formulations (chitosan as monolayer, three layer coating consisting of separate beeswax-chitosan-beeswax layers, three layer coating where chitosan was crosslinked with sodium tripolyphosphate, TPP, and composite). The effectiveness of the coatings was evaluated by the changes of several parameters: fungal infection, weight loss, respiration rate, skin and flesh color, firmness, $\mathrm{pH}$ value, titratabale acidity, soluble solids content, reducing sugars content and sensory evaluation. The coatings, especially the three-layer coatings, significantly decreased the senescence and weight loss of the fruits. They modified the respiration rates of the strawberries and slowed down their metabolism as shown by the retention of the color and the texture of the tissue. Sensory evaluation of the coated strawberries showed that the chitosan and composite coatings gave better visual appearance and taste and were therefore more preferable by $90 \%$ of the judges than the three-layer coatings, even though the later had higher protective effect of the overall quality of the strawberries.
\end{abstract}

(C) 2013 Elsevier Ltd. All rights reserved.

\section{Introduction}

Attempts to reduce the crop losses and maintain the quality of the fresh fruits over extended period has been priority to all food producers. This is true both for fruits being directly sold for consumption or for fruits being subjected to further processing. For the consumers, the most important attributes of fresh fruits are flavor and appearance, as well as their safety and nutritional value.

Strawberries are one of the most popular summer fruits worldwide that are characterized with unique and highly desirable taste and flavor. They are rich in polyphenols and anthocyanins, vitamins and amino acids. The main characteristics related to the quality of the ripe strawberries are their texture, flavor (organic acids and soluble sugars content) and color (Campaniello, Bevilacqua, Sinigaglia, \& Corbo, 2008; Koyuncu \& Dilmaçünal, 2010). Due to their very active metabolism strawberries are highly perishable and have high physiological postharvest activities which lead to short ripening and senescence

\footnotetext{
* Corresponding author. Tel.: +389 23088 269; fax: +389 23065389

E-mail address: elenavelickova@yahoo.com (E. Velickova).
}

periods that make their marketing a challenge (Garcia, Martino, \& Zaritzky, 1998). Loss of quality in this fruit is connected with its sensitivity to fungal infection and susceptibility to water loss, bruising, mechanical injuries and texture softening due to the lack of protective rind (Atress, El-Mogy, Aboul-Anean, \& Alsanius, 2010).

Several preservation techniques such as refrigeration, synthetic chemical fungicides, modified atmosphere packaging, osmotic treatments, hypobaric treatments and heat treatments have been studied to extend the shelf life of fresh or minimally processed strawberries (An, Park, \& Lee, 2009; Castello, Fito, \& Chiralt, 2010; Harker, Redgwell, Hallet, Murray, \& Carter, 2000; Vicente, Costa, Martinez, Chaves, \& Civello, 2005; Wszelaki \& Mitcham, 2000; Zhu \& Zhou, 2007). In the last several years, edible coatings have been widely studied for preservation of fruits and vegetables. Their beneficial effects and easy handling made them broadly applicable to soft fruits as the berries. The main functional advantages attributed to use of edible coatings are slower respiration rate, extended storage periods, firmness retention and controlled microbial growth (Fan et al., 2009; Garcia, Pereira, de Luca Sarantopoulos, \& Hubinger, 2010; Vu, Hollingsworth, Leroux, Salmieri, \& Lacroix, 2011). 
Development of edible coatings has been based upon the use of polysaccharides, proteins, lipids or their combination in different ways. Polysaccharides and proteins are known to form films with good mechanical properties, but with poor permeability, while the lipids form brittle films but with improved permeability. Therefore, the newly developed coatings are focused on combining the polymer matrix with some hydrophobic component (Navarro-Tarazaga, Sothornvit, \& Perez-Gago, 2008; Zúñiga et al., 2012).

Previous studies related to chitosan indicated its potential to prolong storage period and control decay of many fruits, including strawberries (Hernández-Muñoz, Almenar, Ocio, \& Gavara, 2006; Lin, Du, Liang, Wang, \& Yang, 2011; Vargas, Albors, Chiralt, \& González-Martínez, 2006). The wide application of chitosan as edible coating material stem from its good biocompatibility, biodegradability, antibacterial and antifungal activity, membrane forming capacity and safety. The disadvantages of the chitosan films and coatings lay in its relatively high water vapor permeability and possibility to cause allergies to some people. To this date Wong, Gastineu, Gregorski, Tillin, and Pavlath (1992) added saturated fatty acids and fatty acid esters; Vargas et al. (2006) added unsaturated fatty acids and Perdones, Sanchez-Gonzalez, Chiralt, and Vargas (2012) added lemon essential oil to chitosan based coatings to improve their barrier properties to water vapor transfer. So far, there are no data reported on the combined effect of beeswax and chitosan coatings on the water vapor permeability. Furthermore, the vast majority of the published papers focused on the quality of coated strawberries during refrigerated storage $\left(4-8{ }^{\circ} \mathrm{C}\right)$. Therefore, the first goal of the presented work was to study the effect of chitosan based mono- and three layered coatings modified with beeswax and sodium tripolyphosphate on the quality attributes of less investigated strawberry variety Fragaria ananassa cv Camarosa. Chitosan coatings could be prepared in a wide range of concentrations (Mitra \& Dey, 2011). During preliminary laboratory testing the $0.8 \mathrm{~g} / 100 \mathrm{~g}$ chitosan solution provided good adhesion to the fruit and it was chosen for further experiments. Three layered coatings (beeswax-chitosan-beeswax) were prepared to improve the water vapor permeability barrier of the original chitosan films and to avoid the direct contact of the hydrophilic chitosan films with the fruit and the atmosphere. The second goal was to evaluate the quality of coated strawberries at ambient temperature of $20{ }^{\circ} \mathrm{C}$ instead of refrigerated storage. Non-coated fruits and fruits coated with four different types of coatings were compared and analyzed in terms of fungal infection, weight loss, respiration rate, firmness retention, skin and flesh color development, titratable acidity, soluble solids, reducing sugar content and sensory evaluation.

\section{Material and methods}

\subsection{Raw material and chemicals}

Strawberries (Fragaria ananassa cv Camarosa) were purchased in a local supermarket, Continente, Lisbon, Portugal. All fruits were selected based on the same ripening stage ( $>75 \%$ red surface color), uniform size (height: $30 \pm 2 \mathrm{~mm}$; width: $27 \pm 3 \mathrm{~mm}$ ), absence of any physical damage and fungal infection. The strawberry composition was determined by the producer and it contained $0.7 \mathrm{~g} / 100 \mathrm{~g}$ proteins, $7.0 \mathrm{~g} / 100 \mathrm{~g}$ carbohydrates, $0.5 \mathrm{~g} / 100 \mathrm{~g}$ fat, $46 \mathrm{mg} / 100 \mathrm{~g}$ vitamin $C$ and $200 \mathrm{mg} / 100 \mathrm{~g}$ polyphenols. The energy value of the strawberries was $35 \mathrm{kcal}$ or $146 \mathrm{~kJ}$.

Beeswax was provided by the beekeeping center at the Instituto Superior de Agronomia in Lisbon, Portugal. All the other chemicals used in the experiments were of analytical grade and were purchased from Panreac Chimica S.A.U., Barcelona, Spain.

\subsection{Beeswax characterization}

\subsubsection{Saponification value}

An amount of $0.30 \pm 0.01 \mathrm{~g}$ beeswax was weighed into a $10 \mathrm{ml}$ screw-capped glass vial. Four milliliters of $4 \mathrm{~mol} / \mathrm{L}$ aqueous $\mathrm{NaOH}$ solution was pipetted into the vial before it was closed and placed into an oven at $100{ }^{\circ} \mathrm{C}$ for $1 \mathrm{~h}$. Next, the aqueous solution was poured into a beaker. About $5 \mathrm{ml}$ of distilled water was used to rinse the vial and the water was later combined with the aqueous solution. Two drops of $1 \mathrm{~g} / 100 \mathrm{~g}$ phenolphthalein TS was used as an indicator. This solution was titrated against a $0.5 \mathrm{~mol} / \mathrm{L}$ aqueous $\mathrm{HCl}$ solution with manual shaking and the end point was carefully monitored. Blank analyzes were also performed. The saponification value (mg $\mathrm{KOH} / \mathrm{g}$ ) was calculated as follows:

Saponification value $=56.1 \times M\left(V_{\mathrm{b}}-V_{\mathrm{s}} / w\right)$

where 56.1 is the molar mass of $\mathrm{KOH}$ in $\mathrm{g} / \mathrm{mol}$; $M$ is the molarity of $\mathrm{HCl}$ solution in $\mathrm{mol} / \mathrm{L} ; V_{\mathrm{b}}$ is the titrated volume of $\mathrm{HCl}$ solution for the blank in $\mathrm{ml} ; V_{s}$ is the titrated volume of $\mathrm{HCl}$ solution for the sample in $\mathrm{ml}$; and $w$ is the weight of the sample in $\mathrm{g}$.

\subsubsection{Acid value}

The beeswax ( $1 \mathrm{~g}$ ) was weighed, placed in an Erlenmeyer flask, and $50 \mathrm{ml}$ of chloroform were added. The flask was placed in an ultrasonic bath for about 5 min. Two drops of $1 \mathrm{~g} / 100 \mathrm{~g}$ phenolphthalein solution were added to the solution before it was titrated with $0.05 \mathrm{~mol} / \mathrm{L} \mathrm{NaOH}$ in methanol. The titration was continued by manually shaking the flask until the indicator turned the clear solution a faint pink color. Blank analyzes were also conducted. The acid value was expressed as $\mathrm{mg} \mathrm{KOH} / \mathrm{g}$, and calculated as follows:

Acid value $=56.1 \times M\left(V_{\mathrm{b}}-V_{\mathrm{s}} / w\right)$

where 56.1 is the molecular weight of $\mathrm{KOH}$ in $\mathrm{g} / \mathrm{mol}$; $M$ is the molarity of $\mathrm{NaOH}$ solution in $\mathrm{mol} / \mathrm{L} ; V_{\mathrm{s}}$ is the titrated volume of $\mathrm{NaOH}$ in methanol used for the sample in $\mathrm{ml} ; V_{\mathrm{b}}$ is the titrated volume of $\mathrm{NaOH}$ in methanol used for the blank solution in $\mathrm{ml}$; and $w$ is the mass of the sample $(\mathrm{g})$.

\subsection{Preparation of the edible films}

Chitosan solution $(0.8 \mathrm{~g} / 100 \mathrm{~g})$ was prepared by dissolving $0.8 \mathrm{~g}$ of chitosan in $100 \mathrm{ml}$ of acetic acid $(1 \mathrm{ml} / 100 \mathrm{ml})$ with continuous stirring at room temperature $\left(20 \pm 2{ }^{\circ} \mathrm{C}\right)$. After, the complete dissolution of the chitosan, $0.2 \mathrm{~g}$ of glycerol and $0.2 \mathrm{~g}$ of Tween 80 , were added and the solution was stirred for another $30 \mathrm{~min}$. Afterward, the chitosan solution was centrifuged for half an hour at $16,900 \mathrm{~g}$ (Hermle Labortechnik, Wehingen, Germany) to separate all the impurities. The resulting solution was used as chitosan coating.

The cross-linking of the chitosan coating was carried with $0.5 \mathrm{~g} /$ $100 \mathrm{~g}$ sodium tripolyphosphate, TPP, prepared as aqueous solutions by dissolving the salt in distilled water under vigorous stirring. The cross-linking lasted few minutes and then the excess of the crosslinking solution was blotted with absorbent paper.

For beeswax coatings, $0.5 \mathrm{~g} / 100 \mathrm{~g}$ wax solution was prepared by melting $0.5 \mathrm{~g}$ of beeswax in $100 \mathrm{ml}$ of ethanol heated to $70^{\circ} \mathrm{C}$. The wax solution was emulsified with $25 \%$ of Tween 80 with respect to the wax content.

The composite coating was prepared by mixing $100 \mathrm{ml}$ of $0.8 \mathrm{~g} /$ $100 \mathrm{~g}$ chitosan solution with $10 \mathrm{~g}$ of wax. The chitosan coating solution was prepared, as described previously, and then heated to $70{ }^{\circ} \mathrm{C}$. The wax was melted in the heated solution and the whole mixture was homogenized for 2 min with Ultra-turrax homogenizer (Cole-Parmer, Vernon Hills, USA) at $8000 \mathrm{rpm}$. 
The chitosan films were casted in a plastic casting container, ensuring that all air bubbles were removed from the viscous medium before casting. The same thickness of the films was controlled by casting $20 \mathrm{ml}$ film forming solution in containers with standard diameter of $90 \mathrm{~mm}$ and height of $20 \mathrm{~mm}$. Afterward they were dried at $40^{\circ} \mathrm{C}$ for $48 \mathrm{~h}$. The dried chitosan films were peeled off the container before further treatment. The cross-linking of the chitosan films was done by covering them with TPP. The cross-linking procedure lasted few minutes and then the excess of the crosslinking solution was poured out and the films were dried at $40{ }^{\circ} \mathrm{C}$. The chitosan films were coated by dipping the films in the heated wax solutions and then letting the chitosan film coated on the both sides to dry at room temperature. The emulsion was casted in plastic casting containers and dried at $40^{\circ} \mathrm{C}$ for $48 \mathrm{~h}$ to produce composite films. All the formulations of chitosan based films are listed in Table 1 . The obtained films were conditioned in a desiccator at 50\% relative humidity and $20 \pm 2{ }^{\circ} \mathrm{C}$ for one week prior to analysis.

\subsection{Film characterization}

\subsubsection{Thickness measurement}

Thickness of the films was measured using a hand-held micrometer (Alves, Costa, \& Coelhoso, 2010). Eight thickness measurements were taken at random positions on each film and the mean was calculated. For the multilayered films measurements were taken after each step and after applying each layer to evaluate the thickness of the separate layers. The mean value for the thickness was used in calculating the film water vapor barrier and mechanical properties.

\subsubsection{Optical properties}

Film color was determined by Dr Lange spectro-color colorimeter (HACH LANGE, Denver, USA) calibrated with a standard white and black tile. The CIE Lab scale was used, lightness, $L$, and chromaticity parameters $a^{*}$ (red-green) and $b^{*}$ (yellow-blue) were measured. Assays were performed by placing the film samples over the standard white tile. Samples were analyzed in five repetitions. The color differences $(\Delta E)$, chroma $(C)$ and $(h)$ values were calculated by the following equations:

$$
\begin{aligned}
& \Delta E=\left(\Delta L^{* 2}+\Delta a^{* 2}+\Delta b^{* 2}\right)^{1 / 2} \\
& C=\left(a^{* 2}+b^{* 2}\right)^{1 / 2} \\
& h_{\mathrm{ab}}=\tan ^{-1}\left(b^{*} / a^{*}\right)
\end{aligned}
$$

where $L^{*}, a^{*}$ and $b^{*}$ values were the color parameters of the films, while the $L^{*}{ }_{0}, a^{*}{ }_{0}$ and $b^{*}{ }_{0}$ values were the color parameters of the white tile.

\subsubsection{Water absorption capacity}

In order to determine the water absorption capacity or swelling degree of the films, three samples from each film were dried under vacuum for $48 \mathrm{~h}$ at $40 \pm 1{ }^{\circ} \mathrm{C}$ as described in the ASTM D5229 method. After weighing, the samples were slowly immersed in water or $1 \mathrm{~mL} / 100 \mathrm{~mL}$ acetic acid $(14.5 \mathrm{~mL})$, with $0.5 \mathrm{~mL}$ of sodium azide solution $(1 \mu \mathrm{g} / 100 \mathrm{~mL})$ to avoid the growth of fungi. The samples were taken out of the liquid, blotted with absorbent paper to remove the excess of water or acetic acid from the surface and weighed again. The procedure was repeated until reaching a constant mass in two consecutive measurements (during 4 days), and the absorption capacity of the films was calculated:

absorption capacity $=\frac{m_{\mathrm{s}}-m_{\mathrm{i}}}{m_{\mathrm{i}}}$

where $m_{\mathrm{s}}$ is the mass of the immersed film $(\mathrm{g})$ and $m_{\mathrm{i}}$ is the mass of the dried film (g).

\subsubsection{Water vapor permeability}

The water vapor permeability was measured gravimetrically according to the ASTM-96-80 protocol. The films were sealed with silicone to the top of a glass petri dish with a diameter of $5 \mathrm{~cm}$ filled with saturated solution of $\mathrm{BaCl}_{2} \times 2 \mathrm{H}_{2} \mathrm{O}$ to provide relative humidity of $90 \%$. The water vapor permeability was measured using films previously conditioned at a relative humidity of $54 \%$. The sealed petri dishes were placed in a desiccator. The bottom of the desiccator was covered with saturated solution of $\mathrm{Mg}\left(\mathrm{NO}_{3}\right)_{2} \times 6 \mathrm{H}_{2} \mathrm{O}$. The temperature and the relative humidity inside the desiccator were set at $27 \pm 2{ }^{\circ} \mathrm{C}$ and $44 \pm 1 \%$. A fan was used to promote the circulation of air inside the desiccator, in order to minimize the mass transfer resistance of the air boundary layer above the membrane. The temperature and relative humidity were measured over time using a thermohygrometer to obtain better control of the set conditions and to keep them constant. The water vapor molar flux $(N)$ was determined by weighing the petri dish in regular time intervals for $24 \mathrm{~h}$. The water vapor permeability was calculated as follows:

$\mathrm{WVP}=\frac{N \times \delta}{\Delta P_{\mathrm{w}}}$

where $\delta$ is the film thickness $(\mathrm{m})$ and $\Delta P_{\mathrm{w}}$ is the water vapor difference between both sides of the film.

\subsubsection{Mechanical properties}

The mechanical properties were studied using a TAXT2 (Stable Micro Systems, England). Tensile strength, TS, and elongation at break, $E$, were determined in accordance with ASTM D-882-91 (1996). Seven sample strips $(20 \times 70 \mathrm{~mm})$ of the films were cut from the conditioned films. Force $(\mathrm{N})$ and deformation were recorded during extension at $0.2 \mathrm{~mm} / \mathrm{s}$ and with an initial distance of $50 \mathrm{~mm}$ between the grips clamping the films. TS was

\begin{tabular}{|c|c|c|c|c|c|c|c|c|c|}
\hline Sample code & Type of film & $\begin{array}{l}\text { Chitosan } \\
\text { (g/100 g) }\end{array}$ & $\begin{array}{l}\text { TPP:Chitosan } \\
\text { ratio }\end{array}$ & $\begin{array}{l}\text { Glycerol } \\
\text { (g/100 g) }\end{array}$ & $\begin{array}{l}\text { Tween } 80 \\
(\mathrm{~g} / 100 \mathrm{~g})\end{array}$ & $\begin{array}{l}\text { Wax } \\
(\mathrm{g} / 100 \mathrm{~g})\end{array}$ & $\begin{array}{l}\text { Original film } \\
\text { thickness }(\mu \mathrm{m})\end{array}$ & $\begin{array}{l}\text { Wax coating } \\
\text { weight }\left(\mathrm{mg} / \mathrm{cm}^{2}\right)^{\mathrm{a}}\end{array}$ & $\begin{array}{l}\text { Wax coating } \\
\text { thickness }(\mu \mathrm{m} / \text { side })^{\mathrm{b}}\end{array}$ \\
\hline B & Monolayer film & 0.8 & 1 & 0.2 & 0.2 & 1 & 52 & 1 & 1 \\
\hline C & Wax coated, multilayer film & 0.8 & l & 0.2 & 0.2 & 0.50 & 52 & 2.50 & 1.5 \\
\hline $\mathrm{D}$ & $\begin{array}{l}\text { Crosslinked, wax coated, } \\
\text { multilayer film }\end{array}$ & 0.8 & $0.3: 1$ & 0.2 & 0.20 & 0.50 & 48 & 2.50 & 2.5 \\
\hline $\mathrm{E}$ & Composite film & 0.8 & 1 & 0.2 & 0.2 & 10 & 60 & 1 & 1 \\
\hline
\end{tabular}

Table 1

Composition and coding of the chitosan-based edible films.

a Wax weight on both sides of the chitosan film.

b Wax thickness per side of the chitosan film. 
calculated by dividing the maximum load by the initial crosssectional area of the sample and expressed in MPa. E was calculated as a ratio of the elongation at the point of sample rupture to the initial length of a sample as a percentage. The Young's modulus, calculated as ratio between the tensile strength and elongation in the elastic deformation region of the stress-strain curve, was also expressed in MPa. The thickness of the chitosan films was $52 \mu \mathrm{m}$, while the thickness of the cross-linked chitosan films was $48 \mu \mathrm{m}$ (Table 1 ).

\subsection{Sample treatment}

Total mass of $8 \mathrm{~kg}$ strawberries were randomly divided into five groups, each group containing 120 strawberries. The group A was used as a control and it consisted of fresh strawberries, without any treatment. The group B consisted of chitosan coated strawberries. The coating was applied by dipping the each fruit in the coating solution for $30 \mathrm{~s}$. The fruits were held by the stem during dipping to avoid any handling injuries. After the dip, the fruits were placed upside down on a plastic support $(20 \times 15 \times 10 \mathrm{~cm})$ with open squares like a wire mesh to allow the settling of the coating. Next group, C, consisted of three-layered coating comprised of waxchitosan-wax coating. In the group $\mathrm{D}$, strawberries were coated with wax, followed by chitosan layer crosslinked with sodium tripolyphosphate, and one more wax layer. The three-layer coating of the strawberries in the groups C and D were formed by firstly dipping the strawberries into the melted solution of beeswax, then after 5 min the strawberries were dipped in the chitosan solution and at the end the fruits were dipped again in the melted beeswax solution. The strawberries in the last $\mathrm{E}$ group were coated with composite coating. Fruits were allowed to dry for $2-4$ h at $20^{\circ} \mathrm{C}$ depending on the coating. A summary of the sample treatment is given in Table 2 . After the settling of the coating the fruits were randomly selected and placed in perforated ( 6 perforations with $10 \mathrm{~mm}$ diameter on the bottom of each box) plastic boxes (capacity: $250 \mathrm{~g}$ ) in one layer for each replicate. Seven replicates were used per treatment. Packaged fruits were stored at $20{ }^{\circ} \mathrm{C}$ temperature and $35-40 \%$ relative humidity for 7 days.

\subsubsection{Coating microscopic examination}

Microscopic examination was performed to evaluate coating uniformity and adherence to the strawberries' surface. Samples from each treatment (chitosan, beeswax, beeswax-chitosanbeeswax and composite coatings) and uncoated controls were analyzed at room temperature. The coating thickness was imaged using an Optical Microscope (Axiostar Plus, Carl Zeiss Light Microscopy, Germany) illuminated with a pre-centered $20 \mathrm{~W}$ halogen lamp. Slices from the surface of the coated strawberries were cut using a stainless steel blade. Sample surfaces of coated strawberry

\section{Table 2}

Coding and treatment of the strawberries.

\begin{tabular}{|c|c|c|c|c|}
\hline \multirow{2}{*}{$\begin{array}{l}\text { Sample } \\
\text { code }\end{array}$} & \multicolumn{4}{|c|}{ Sample treatment } \\
\hline & $\begin{array}{l}\text { Type of } \\
\text { sample }\end{array}$ & Layer & Type of coating & Treatment time \\
\hline A & Control & 1 & None & No treatment \\
\hline B & Coated & 1 & Chitosan & 30 s dipping, $2-4$ h drying \\
\hline C & Coated & 3 & Wax-chitosan-wax & $\begin{array}{l}30 \text { s dipping, } 5 \text { min drying } \\
30 \text { s dipping, } 2-4 \text { h drying } \\
30 \text { s dipping, } 5 \text { min drying }\end{array}$ \\
\hline $\mathrm{D}$ & Coated & 3 & $\begin{array}{l}\text { Wax-chitosan- } \\
\text { TPP-wax }\end{array}$ & $\begin{array}{l}30 \text { s dipping, } 5 \text { min drying } \\
30 \text { s dipping, } 2-4 \text { h drying } \\
30 \text { s dipping, } 5 \text { min cross-linking } \\
30 \text { s dipping, } 5 \text { min drying }\end{array}$ \\
\hline E & Coated & 1 & Composite & 30 s dipping, $2-4$ h drying \\
\hline
\end{tabular}

pieces were observed with $10 \times$ magnification lens (numerical aperture 0.25 ) and the images were analyzed and recorded with software AxioVision 4.8 (Carl Zeiss Light Microscopy, Germany).

\subsubsection{Fruit visual infection}

The strawberries were examined for mold during storage. Fruits from all groups were visually inspected for any signs of mycelia development on the fruit surface. Infected strawberries were characterized as moldy, with brown spots and softening of the infected area. Forty five fruits were used for each measurement and three batches of forty five fruits were prepared for each group, total of 135 strawberries. The results were expressed as the percentage of infected fruit from the starting 135 strawberries.

\subsubsection{Weight loss}

To determine weight loss, the same strawberries were weighed at the beginning of the experiment after the settling of the coating and thereafter each day during the storage period. Weight loss was expressed as the percentage loss of the initial total weight. Ten fruits in three repetitions were used to evaluate the weight loss of every group.

\subsubsection{Respiration rate}

In order to measure the respiration rate a closed system was used. Strawberry samples (around $115 \mathrm{~g}$ ) were placed in $1.02 \mathrm{~L}$ hermetic glass jars with a septum in the lid for sampling gas in the headspace at different sampling times, over period of $44 \mathrm{~h}$. The jars were stored at ambient temperature of $20^{\circ} \mathrm{C}$. Gas sampling was carried out every $30 \mathrm{~min}$, in the first $5 \mathrm{~h}$, then after $90 \mathrm{~min}$ till the 9 th $\mathrm{h}$ and once per day till $44 \mathrm{~h}$ by means of a needle probe connected to a gas analyzer (CheckMate 9900 PBI Dansensor, Ringsted, Denmark). The needle probe was pushed through the septum and the headspace gas analyzer based on a mini-IR spectrophotometer recorded the $\mathrm{CO}_{2}$ content. Three replicates were performed for each coating treatment. The respiration rate was calculated by using the following equation:

Respiration rate $=\frac{\Delta \mathrm{CO}_{2}}{100} \cdot V_{\text {headspace }} \cdot \frac{1000}{m} \cdot \frac{60}{t}\left(\mathrm{ml} \mathrm{CO}_{2} / \mathrm{kgh}\right)$

where $m$ is mass of strawberry ( $\mathrm{g}$ ); $V_{\text {headspace }}$ is the empty volume of the hermetic jar ( $\mathrm{ml}) ; \Delta \mathrm{CO}_{2}$ is the difference between the initial and final concentration of $\mathrm{CO}_{2}$ and $t$ is sampling time (min).

\subsubsection{Skin and flash color evaluation}

The color of strawberry skin and inside flesh was evaluated on control and treated strawberries using a colorimeter (Konica Minolta, Sensing, Spectro photo meter CR-300, Osaka, Japan) to obtain $L^{*}$ (lightness), $a^{*}$ (redness) and $b^{*}$ (yellowness) values as mean of 10 readings. Surface color was measured by placing the whole fruits against the colorimeter, while for the inside flesh, the strawberries were cut in halves and measured. The total color difference $\Delta E$, as well as the chroma value, $C$, and hue angle, $h_{\mathrm{ab}}$, were calculated using the Equations (3)-(5).

\subsubsection{Measurement of fruit firmness}

The firmness of the fresh, control, and coated strawberries was measured at $20^{\circ} \mathrm{C}$ using a texture analyzer (TA-XT2i of Stable Micro Systems, Godalming, England) with a $5 \mathrm{~kg}$ load cell. The cutting method according to Velickova et al. (2011), was slightly modified. In brief, crosshead speed was set at $1 \mathrm{~mm} / \mathrm{s}$ and the penetration depth was $20 \mathrm{~mm}$. A single, whole, strawberry was placed on a flat platform and a sharpened $5 \mathrm{~mm}$ diameter cork borer adapted to fit the texture analyzer was used to cut through the strawberry tissue from one side to another, penetrating to $55 \%$ of the total fruit width. 
The textural parameter measured on the resulting force-distance curves was firmness and the mean values of six replicates, expressed in $N$, were reported. The coating effect on the surface and core firmness was calculated as

Coating effect $=\ln \left(F_{\mathrm{c}} / F_{\mathrm{r}}\right)$

where $F_{\mathrm{c}}$ is the maximum force of the coated fruit and $F_{\mathrm{r}}$ is the maximum force of the raw fruit.

\subsection{7. $\mathrm{pH}$, titrable acidity (TA) and soluble solids content (SSC)}

After the measurement of the firmness, the strawberries cut into small pieces were homogenized for $1 \mathrm{~min}$ at high speed using a hand-held blender. The variety Camarosa, being a larger fruit, provided a sufficient fruit mass for all the chemical analyzes. The $\mathrm{pH}$ of the strawberry puree was measured with a calibrated $\mathrm{pH}$ meter. For the chemical analyzes $5 \mathrm{~g}$ of the homogenized strawberry puree was suspended in $50 \mathrm{ml}$ of hot distilled water $\left(80^{\circ} \mathrm{C}\right)$ for $30 \mathrm{~min}$ and then filtered. This solution was titrated to $\mathrm{pH} 8.1$ using $0.1 \mathrm{~mol} / \mathrm{L} \mathrm{NaOH}$. The total titrable acidity of the diluted puree was calculated using the formula:

Titratable acidity $=\frac{V(\mathrm{NaOH}) \cdot 0.1 \cdot 0.064}{m_{\text {aliquote }}} \cdot 100(\%)$

Where $V(\mathrm{NaOH})$ is the $\mathrm{ml}$ of $\mathrm{NaOH}$ spent for titration, 0.1 is the molarity of the $\mathrm{NaOH}$ solution, 0.064 is conversion factor for citric acid and $m_{\text {aliquot }}$ is the mass of the aliquot sample taken for analysis. The soluble solids content was determined in the juice of blended strawberries by means of an Atago PAL-1 digital refractometer at $20{ }^{\circ} \mathrm{C}$ and expressed as a percentage. All measurements were done in triplicate.

\subsubsection{Reducing sugar content}

For the determination of reducing and total sugar content, $5 \mathrm{~g}$ of the homogenized strawberry puree was suspended in $50 \mathrm{ml}$ of hot distilled water $\left(80^{\circ} \mathrm{C}\right)$ for $30 \mathrm{~min}$ and then filtered. The content of reducing sugars was determined using a reducing chemical reagent, 3,5-dinitrosalycilic acid solution following the procedure described by Miller (1959).

\subsubsection{Sensory analysis}

Sensory evaluation of the strawberries was carried out in a standardized test room, in the sensory laboratory of the Department of Food Science and Technology, ISA/UTL, 3 days after the coating application. Fresh strawberries were used as control samples. Samples were given to each judge in a completely randomized order, served on white saucers and labeled with three digit random numbers. The sensorial attributes of the fruits such as appearance, in terms of shininess, presence of aftertaste, sweetness, overall acceptance and intention to buy were evaluated by seven trained judges. The panel of trained judges consisted of food engineers among which 2 men and 5 women in the age range from 30 to 65 years. The attributes were ranked on 6-points intensity scale where the score for the absence of gloss, absence of aftertaste, no sweetness, no acceptance and no intention to buy was (1), while (6) was given to samples with very high gloss, strong aftertaste, extremely high sweetness, very high overall acceptance and definite intention to buy. An average score of 3.5 and above was considered as limit for acceptability for all the attributes, except the presence of aftertaste, where score below 3.5 was considered acceptable. After the attributes ranking the judges were asked to order the samples according to their preference in decreasing order.

\subsection{Statistical analysis}

Descriptive statistics and one-way analysis of variance (ANOVA) was performed on the instrumental and sensory parameters to evaluate significant differences among the samples at 95\% confidence interval according to Tukey's test using Minitab 15 statistical software. The variables that showed high significance were used in the Principal Component Analysis (PCA) to identify a reduced number of principal components that sufficiently explain most of the information in the starting data. This analysis was a multilinear modeling method of pattern recognition which shows the relationship between the objects (groups) on the basis of their distribution in the multidimensional space described from all the variables and also made it possible to determine which variables are principally responsible for the separation of the objects. The data obtained from all analysis (sensory, chemical and mechanical properties) of the strawberries were also analyzed by means of multivariate analysis employing hierarchical cluster analysis. The method used was Ward's method. The distances between samples were calculated using square Euclidean distances.

\section{Results and discussion}

\subsection{Characterization of the edible films}

The chitosan films were easy to peel from the casting container. They were transparent, homogenous, thin, flexible and easy to handle. The addition of the glycerol and Tween 80 to the chitosan solution resulted in films with a slightly yellow appearance. The beeswax, used in these studies, was a yellowish waxy solid with density of $850 \mathrm{~kg} / \mathrm{m}^{3}$ at room temperature, acid value of $16.12 \pm 1.2 \mathrm{mg} \mathrm{KOH} / \mathrm{g}$ and saponification value of $92.01 \pm 1.56 \mathrm{mg}$ $\mathrm{KOH} / \mathrm{g}$. The melting point of the wax was around $61{ }^{\circ} \mathrm{C}$. The four types of the prepared edible films and their properties are presented in Table 3. The use of the waxy coating to the chitosan films resulted in multilayered films with mat look and decreased transparency, while the composite films had a more intensive yellowbrownish color. The applied cross-linking procedure made the films glossier, harder and slightly brittle.

The thickness of the edible films is very important for the physical properties of the films. The average thickness values for all chitosan-based films were from 48 to $60 \mu \mathrm{m}$. The cross-linked chitosan films exhibited reduced thickness, while the wax coated films had slightly increased thickness. The thickness of the composite films was similar to the one of pure chitosan films.

The water absorption capacity of the films was higher in acetic acid than in distilled water. The degree of absorption capacity of chitosan films in distilled water was $1.21 \pm 0.247 \%$ which is similar to the results for absorption capacity of chitosan films in distilled water of $1.73 \%$ reported by Mayachiew, Devahastin, Mackey, and Niranjan (2010). A higher water absorption capacity was observed for the multilayered films, when compared to the single chitosan films. This increase might be due to water entrapped in small pores between the film and the wax layers. The composite films showed a significantly lower absorption capacity in water compared to the other films. The presence of the beeswax as a component in the composite films prevents the water absorption due to its hydrophobic nature.

The optical properties of the edible films are also important for the consumer's acceptability of the product. Transparent films are less likely to change the appearance of the strawberries. All films exhibited a yellowish color, which is reflected on a hue value near $90^{\circ}$. The addition of wax, in the multilayered films and the composite films, did not change significantly the hue value of the edible films. The calculated values for overall color change $(\Delta E)$ revealed 
Table 3

Parameters of the edible films.

\begin{tabular}{|c|c|c|c|c|c|c|c|c|c|c|}
\hline \multirow[t]{2}{*}{ Sample code } & \multirow{2}{*}{$\begin{array}{l}\text { Film thickness }^{\mathrm{a}} \\
(\mu \mathrm{m})\end{array}$} & \multicolumn{2}{|c|}{ Absorption capacity ${ }^{\mathrm{b}}$} & \multicolumn{3}{|c|}{ Optical properties $^{c}$} & \multirow{2}{*}{$\begin{array}{l}\begin{array}{l}\text { Water vapor } \\
\text { permeability }^{\mathrm{d}}\end{array} \\
\left(\mathrm{mol} \mathrm{m} / \mathrm{m}^{2} \mathrm{~s} \mathrm{~Pa}\right)\end{array}$} & \multicolumn{3}{|c|}{ Mechanical properties ${ }^{\mathrm{e}}$} \\
\hline & & Water (\%) & $\overline{\text { Acetic acid (\%) }}$ & $\bar{E}$ & $C$ & $h^{\circ}$ & & Tension (MPa) & $\varepsilon(\%)$ & $\begin{array}{l}\text { Young's modulus } \\
(\mathrm{MPa})\end{array}$ \\
\hline B & $52 \pm 7$ & $1.2 \pm 0.3$ & $2.8 \pm 0.4$ & $15.6 \pm 0.5$ & $17.0 \pm 0.5$ & $82.2 \pm 2.6$ & $4.15 \times 10^{-11}$ & $10 \pm 2.1$ & $24 \pm 2.1$ & $42 \pm 3.8$ \\
\hline $\mathrm{C}$ & $55 \pm 2$ & $4.6 \pm 0.7$ & $5.9 \pm 0.9$ & $20.8 \pm 0.6$ & $23.1 \pm 0.7$ & $84.0 \pm 2.5$ & $2.66 \times 10^{-11}$ & $11 \pm 1.8$ & $20 \pm 2.9$ & $56 \pm 6.8$ \\
\hline $\mathrm{D}$ & $48 \pm 7$ & $4.6 \pm 0.2$ & $6.9 \pm 1.0$ & $15.2 \pm 0.4$ & $17.4 \pm 0.5$ & $83.0 \pm 2.5$ & $3.26 \times 10^{-11}$ & $23 \pm 2.2$ & $5 \pm 0.7$ & $425 \pm 18.8$ \\
\hline E & $60 \pm 7$ & $0.7 \pm 0.1$ & $4.3 \pm 1.0$ & $19.0 \pm 0.6$ & $21.2 \pm 0.6$ & $85.4 \pm 2.5$ & $1.66 \times 10^{-11}$ & $1 \pm 0.1$ & $25 \pm 2.5$ & $4 \pm 0.7$ \\
\hline
\end{tabular}

a Number of replications, $n=8$.

b $n=3$.

c $n=5$.

${ }^{\mathrm{d}} n=3$.

e $n=7$.

the color differences among the four different edible films. The values of $\Delta E$ were low, but still revealed the mat look and loss of shininess of the color wax coated chitosan films.

The water vapor permeability of the chitosan films was expected to be reduced by the modification of the edible films with crosslinking, coating and preparation of composite films. The results confirmed that the wax coating decreased the permeability of the initial chitosan films (B) from $4.15 \times 10^{-11} \mathrm{~mol} \mathrm{~m} / \mathrm{m}^{2} \mathrm{~s}$ Pa to $2.66 \times 10^{-11}$ and $3.66 \times 10^{-11} \mathrm{~mol} \mathrm{~m} / \mathrm{m}^{2} \mathrm{~s}$ Pa for wax coated films (C and D). Similar results of improved barrier properties by application of lipid layers were reported by several other authors, using different waxes, such as beeswax, paraffin wax and carnauba wax as a coating of the polysaccharide edible films (Debeaufort \& Voilley, 1995; Martin-Polo et al., 1992). The composite films (E) presented water vapor permeability 2.5 times lower than that of the chitosan films (B).

From the analysis of the mechanical properties it was proven that different treatments resulted in films with different mechanical properties. The crosslinking of chitosan films produced considerably stiffer film with increased tensile strength at break (from $10 \mathrm{MPa}$ for B to $23 \mathrm{MPa}$ for D), decrease of elongation at break (from $24 \%$ for B to 5\% for D) and increase of Young's modulus (from $42 \mathrm{MPa}$ for B to $425 \mathrm{MPa}$ for D). The beeswax coating of the chitosan film did not affect significantly $(p<0.05)$ the tensile strength at break, the elongation at break or the Young's modulus of the original chitosan films. The incorporation of the beeswax in the composite films formed very fragile and less stiff edible films.
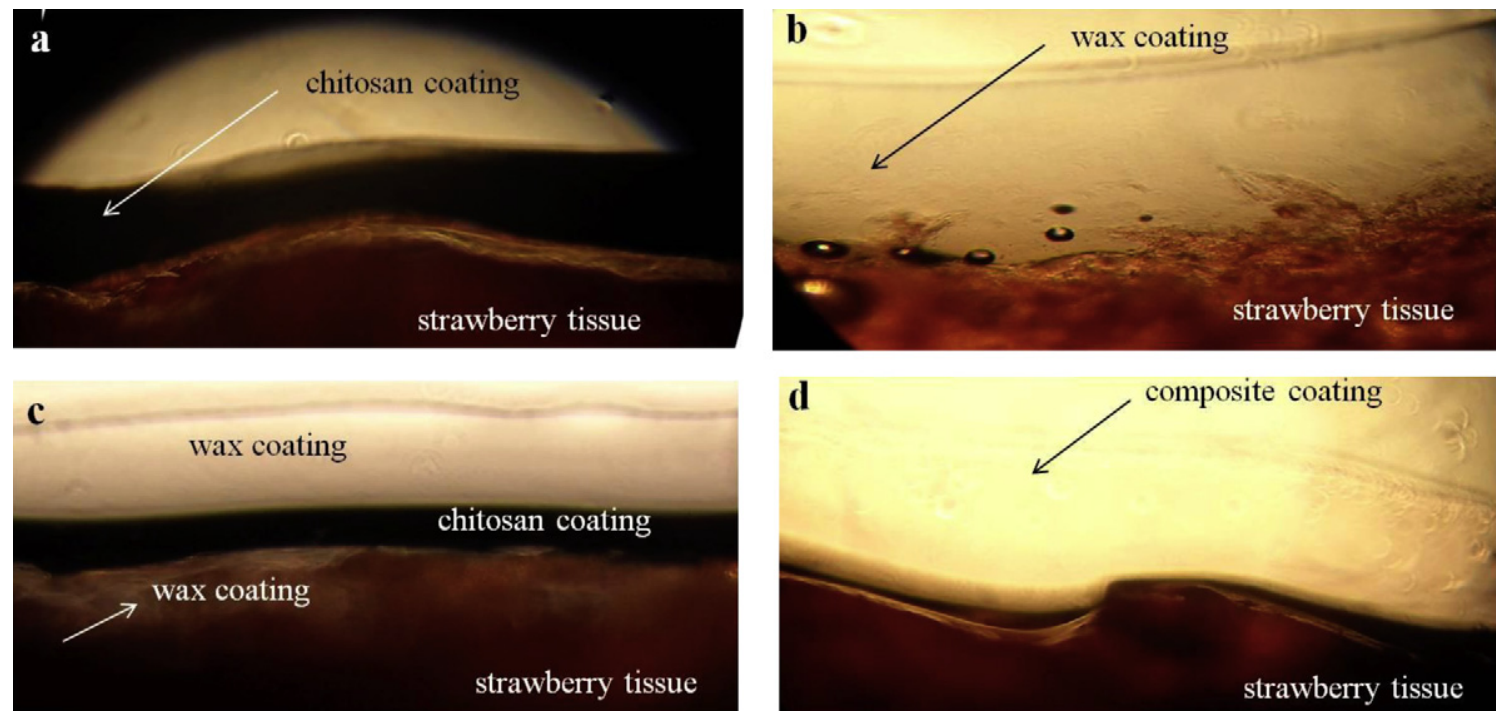

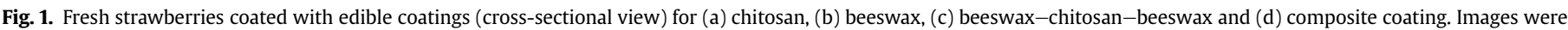
obtained using light microscope Axiostar Plus, Carl Zeiss, 10× magnifications. 


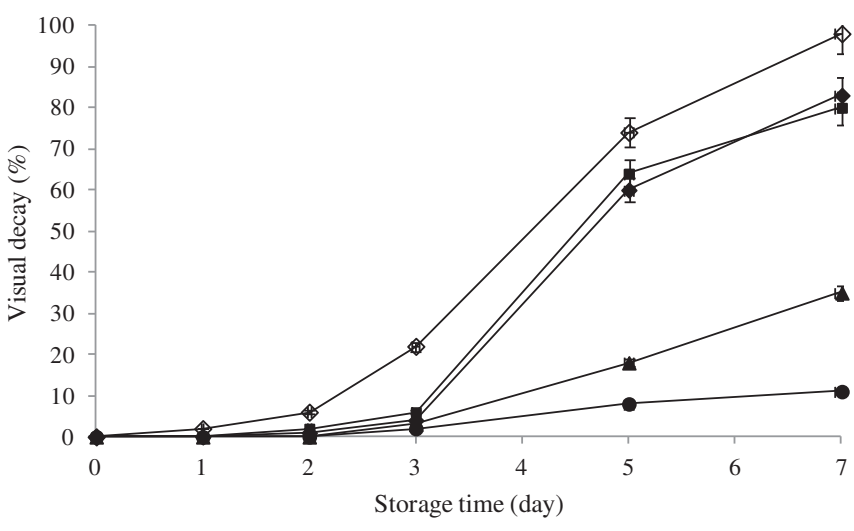

Fig. 2. Percentage of infected strawberries as a function of storage time at $20{ }^{\circ} \mathrm{C}$ and $35-40 \%$ RH for control (open diamonds, $\diamond$ ), chitosan (full squares, $\mathbf{\square}$ ), beeswaxchitosan-beeswax (full triangles, $\boldsymbol{\Lambda}$ ), beeswax-chitosan-TPP-beeswax (full circles, -) and composite coated samples (full diamonds, $\bullet$ ). Vertical bars represent the standard deviation $(n=3)$.

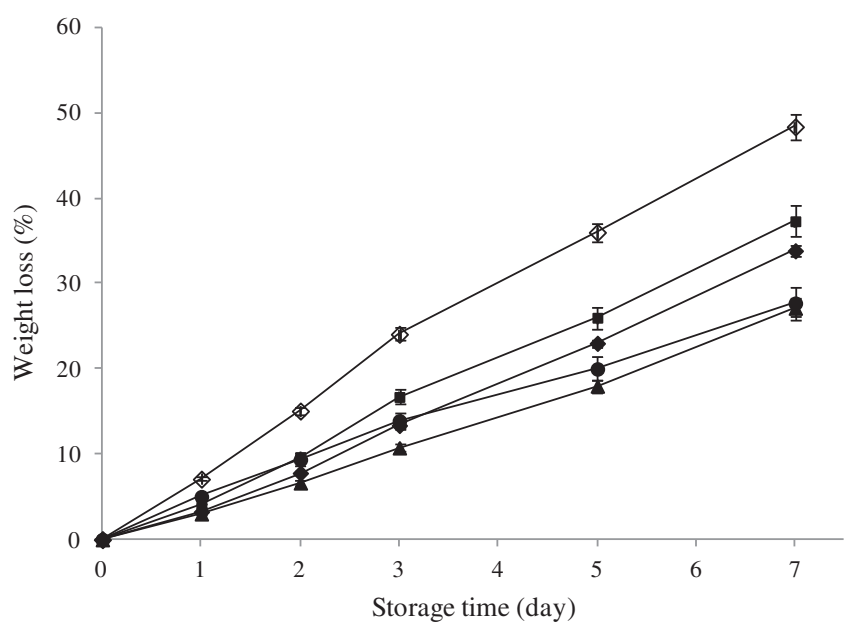

Fig. 3. Loss of weight of strawberries as a function of storage time at $20^{\circ} \mathrm{C}$ and $35-40 \%$ relative humidity for control (open diamonds, $\diamond$ ), chitosan (full squares, $\mathbf{a}$ ), beeswax-chitosan-beeswax (full triangles, $\boldsymbol{\Delta}$ ), beeswax-chitosan-TPP-beeswax (full circles, -) and composite coated samples (full diamonds, $\bullet$ ). Vertical bars represent the standard deviation $(n=3)$. treated with composite coatings (E) were around $80 \%$, while the infection of the three-layer coated strawberries (C and D) was 35 and $11 \%$, respectively. These results agree with findings of Vargas et al. (2006), who reported that the presence of lipid components enhanced the antimicrobial properties of chitosan. HernándezMuñoz, Almenar, Del Valle, Velez, and Gavara (2008) proved that the antimicrobial activity of chitosan on strawberries was related to its ability to cause severe cellular damage to the molds and interfere in the secretion of polygalacturonases rather than its ability to induce plant defense enzymes.

\subsection{Weight loss}

Strawberry fruits are highly susceptible to rapid loss of water which results in fruit shrinkage and weakening of the tissue due to their very thin skin. Therefore, the weight loss was followed over the storage period of 7 days to evaluate the effects of the coatings. All fruits exhibited a continuous weight loss over the storage period (Fig. 3). Nevertheless, after the second day of storage, weight loss for all coated strawberries was significantly lower $(p<0.05)$ than those of the control fruits. At the 7 th day of storage at $20^{\circ} \mathrm{C}$, the weight loss was $11 \%$ lower for chitosan coated fruits compared to control samples which exhibited $48 \%$ loss of the initial weight. Obviously chitosan acted as physical barrier to moisture loss and constrained the dehydration and shrinkage of the fruits. The addition of beeswax as a separate coating layer or as a component in the composite coating exhibited higher reduction in the loss of weight which was $15-20 \%$ lower than the control fruits for the composite (E) and three-layered coatings (C and D), respectively. Similar results for improved barrier properties due to the presence of the lipid component were reported for gluten based coatings modified with beeswax, stearic and palmitic acid and for hydroxypropyl methylcellulose coatings modified with beeswax (NavarroTarazaga et al., 2008; Tanada-Palmu \& Grosso, 2005).

\subsection{Respiration rate}

It is known that the storage at elevated temperatures enhances the respiration process of the fruits. The respiration of the control and coated strawberries was followed over period of time to evaluate the effect of the coatings on the respiration rate of strawberries at $20^{\circ} \mathrm{C}$. The respiration rate was calculated and only the

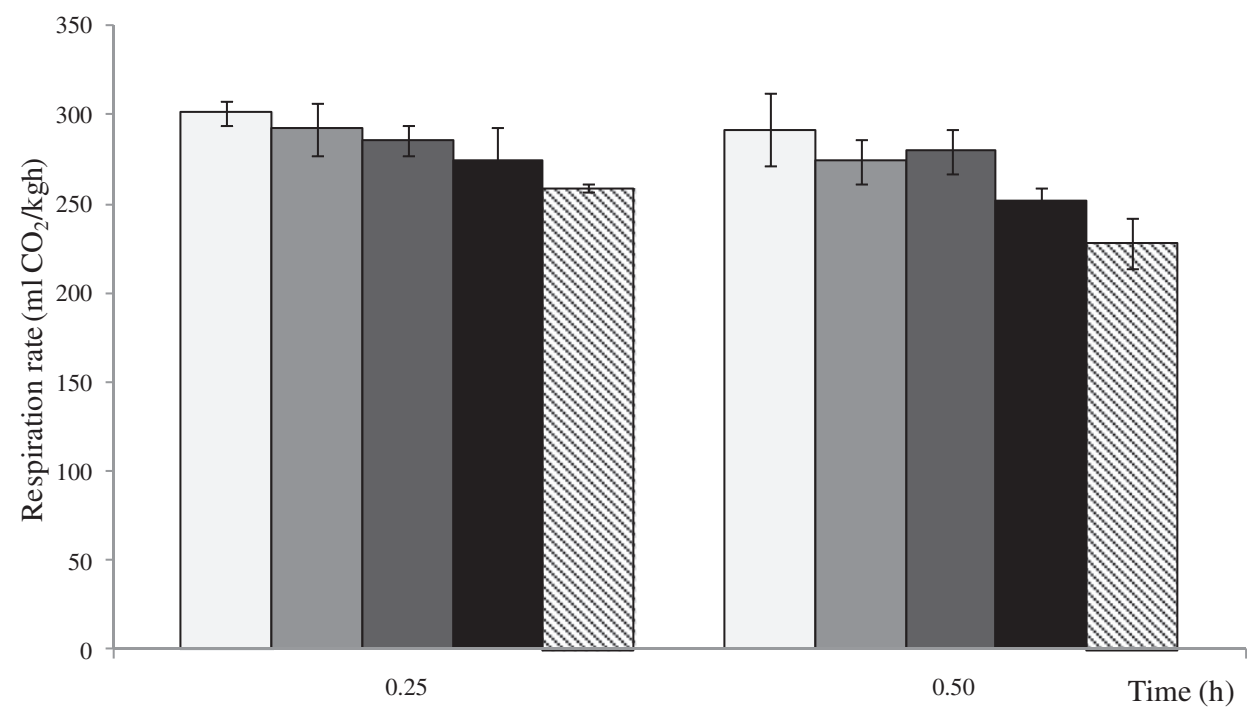

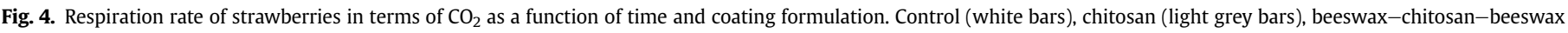
(dark grey bars), beeswax-chitosan-TPP-beeswax (black bars) and composite coated samples (patterned bars). Vertical bars represent the standard deviation $(n=3$ ). 

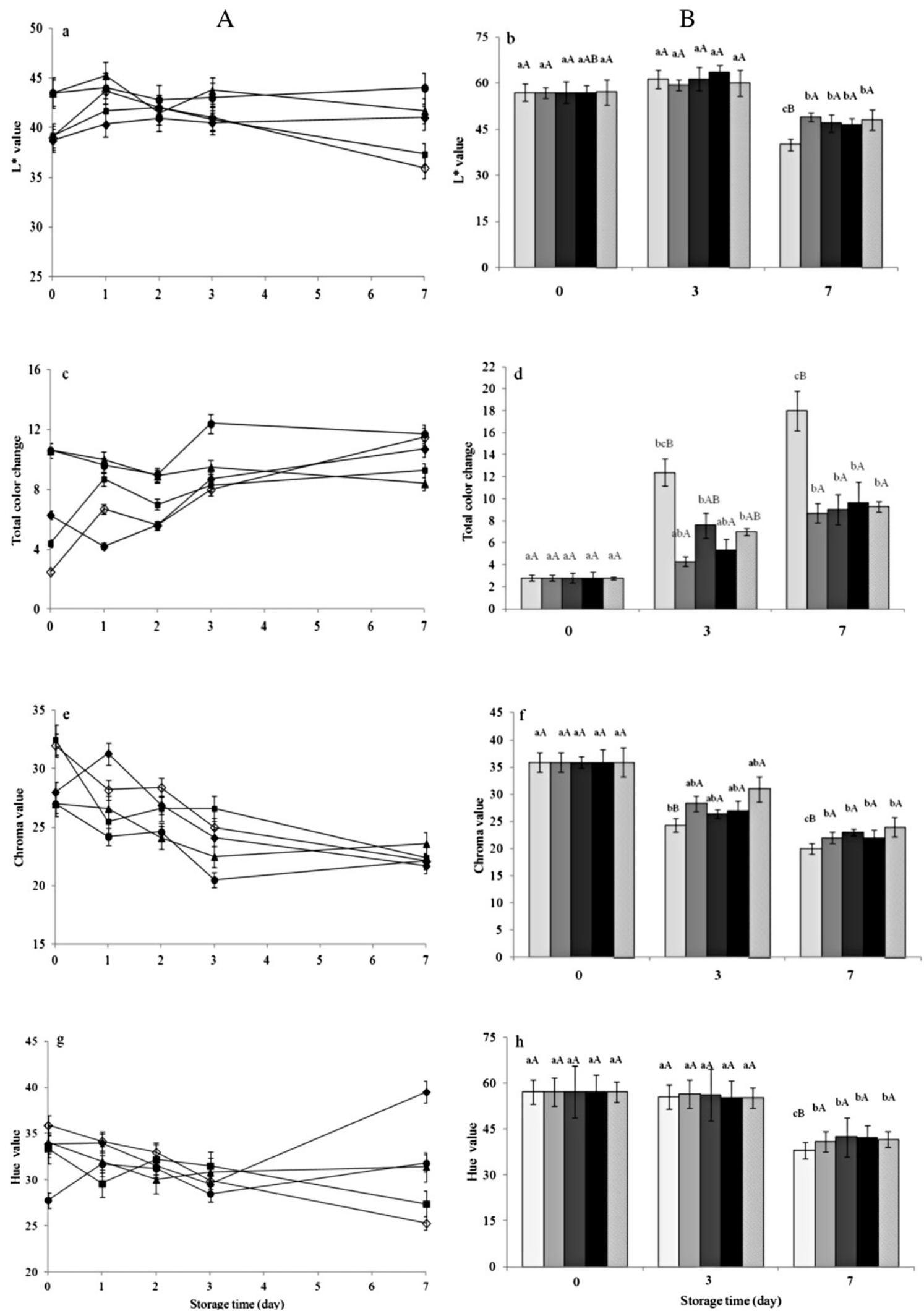

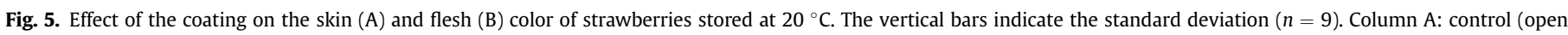

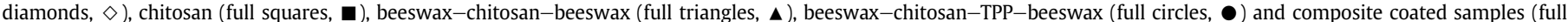

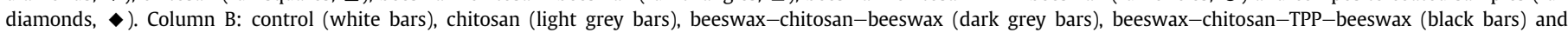

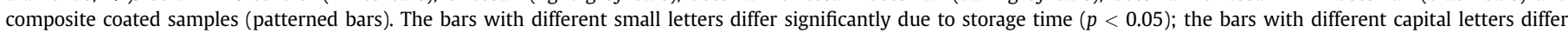
significantly among coatings $(p<0.5)$. 
results from the first half an hour, until the saturation point with $\mathrm{CO}_{2}$, were given in Fig. 4. The ANOVA analysis showed that the time and coating formulation affected the respiration rate significantly $(p<0.05)$. It was evident that the coatings controlled the exchange of the gases between the fruit and the environment due to their different permeability to gases like $\mathrm{CO}_{2}$ and $\mathrm{O}_{2}$. Incorporation of the beeswax in the coating significantly reduced the respiration rate of the strawberries, which is in agreement with the reported effect of lipids on the gas barrier properties of polysaccharide films (Vargas et al., 2006). The values of $291.7 \mathrm{ml} \mathrm{CO}_{2} / \mathrm{kgh}$ for the control samples (A) and 274.3 (B); 279.7 (C); 252.1 (D) and 227.9 (E) $\mathrm{ml} \mathrm{CO}_{2} / \mathrm{kgh}$ for the coated samples obtained after $0.5 \mathrm{~h}$ are comparable with the results reported by Lima et al. (2010) when working with sliced and then coated apples and mangoes stored at $20^{\circ} \mathrm{C}$. The modification of the gas balance in the microenvironment of the fruits led to their decreased respiration and hence better preservation.

\subsection{Skin and flash color development}

Changes in the skin and flash color of the control and coated strawberries were evaluated by measuring the luminosity $\left(L^{*}\right)$, total color change $(\Delta E)$, hue angle and chroma during 7 days of storage at $20{ }^{\circ} \mathrm{C}$. Values for the strawberry skin are presented in Fig. 5, A column, while the values for the inside flesh are presented in Fig. 5, B column. After the coating application the strawberries coated with beeswax had slightly higher $L^{*}$ values due to the whitish and mat look of the beeswax coating. As it could be seen, there was a slight visual color difference between the beeswax coated and the other samples. There were no significant changes $(p>0.05)$ of the luminosity of the samples until the third day of the storage. Only at the end of the storage the control and chitosan coated sample showed significant darkening of the skin $(p<0.05)$. The inside flash also developed darker color at the end of the storage period in all samples, and the control sample was significantly darker than the rest of the fruits.

The total color change of beeswax coated samples was significantly higher $(p<0.05)$ at the beginning, but was kept more or less constant over the storage. The color change of the control samples and samples coated with chitosan and composite coatings increased with time. The control fruits exhibited four and six-fold higher values of the total color change at the third and seventh day of storage, respectively. In contrast, the color change of the coated fruits increased only three times at the end of the storage. There were no significant differences $(p>0.05)$ in terms of hue or chroma due to the coatings. The chroma and hue values of the strawberry skin decreased over time about $30 \%$ for the control and between 10 and $23 \%$ for differently coated samples, which could be attributed to the drying of the surface. The inside flash on the other hand did not change significantly at the beginning. The control samples always had lower values for the chroma and hue when compared to the coated fruits. There were no tissue damages and lesions of the inside flash of the coated strawberries until the third day of storage at $20^{\circ} \mathrm{C}$. The most noticeable color changes during storage occurred in the control samples due to the advanced atmospheric dehydration. The absence of the coating, which acted as protective barrier, accelerated the senescence of the fruit, causing loss of the intracellular liquid and tissue collapse (Figs. 2 and 3). The storage temperature of $20^{\circ} \mathrm{C}$, compared to refrigerated storage, increased the respiration of the fruit and gave rise to some enzymatic processes that caused darkening of the strawberries. The evidence for this was found in the lower chroma (less vivid) and hue angle (less red). The senescence delay, evidenced by the decrease in color changes, which demonstrated the effectiveness of the coatings was reported for the chitosan-oleic acid edible coatings (Vargas et al., 2006); alginate coatings (Fan et al., 2009) and soy protein and wheat gluten coatings (Atress et al., 2010).

\subsection{Fruit firmness}

Strawberries soften considerably during ripening due to degradation of the middle lamella of the cell wall of cortical parenchyma cells (Perkins-Veazie, 1995). Therefore the texture of the strawberry is a very important quality parameter. The changes of the surface and core firmness of the control and treated strawberries were determined with cutting method (Velickova et al., 2011). In the beginning of the curve there was a rapid increase of the force up to a yielding point, where strawberries were slightly deformed and compressed without any cutting of the tissue (Fig. 6a). The end of first peak indicated the point of internal fracture and has been taken as the parameter to measure surface firmness. The firmness of the strawberries core, also known as pith, is given by the second peak on the curve. The effect of the different coatings on the surface and core firmness of the strawberries is presented in Fig. 6b. The three-layer coating of the strawberry with beeswax-crosslinked chitosan-beeswax led to significant softening of the strawberry surface $(p<0.05)$, while the other coating formulations did not cause significant softening of the surface when compared to the fresh strawberries. The strawberry core, on the other hand, exhibited different behavior. The coating application did not cause any softening of the inside flash. Furthermore, the three-layer coating of beeswax-chitosan-beeswax even
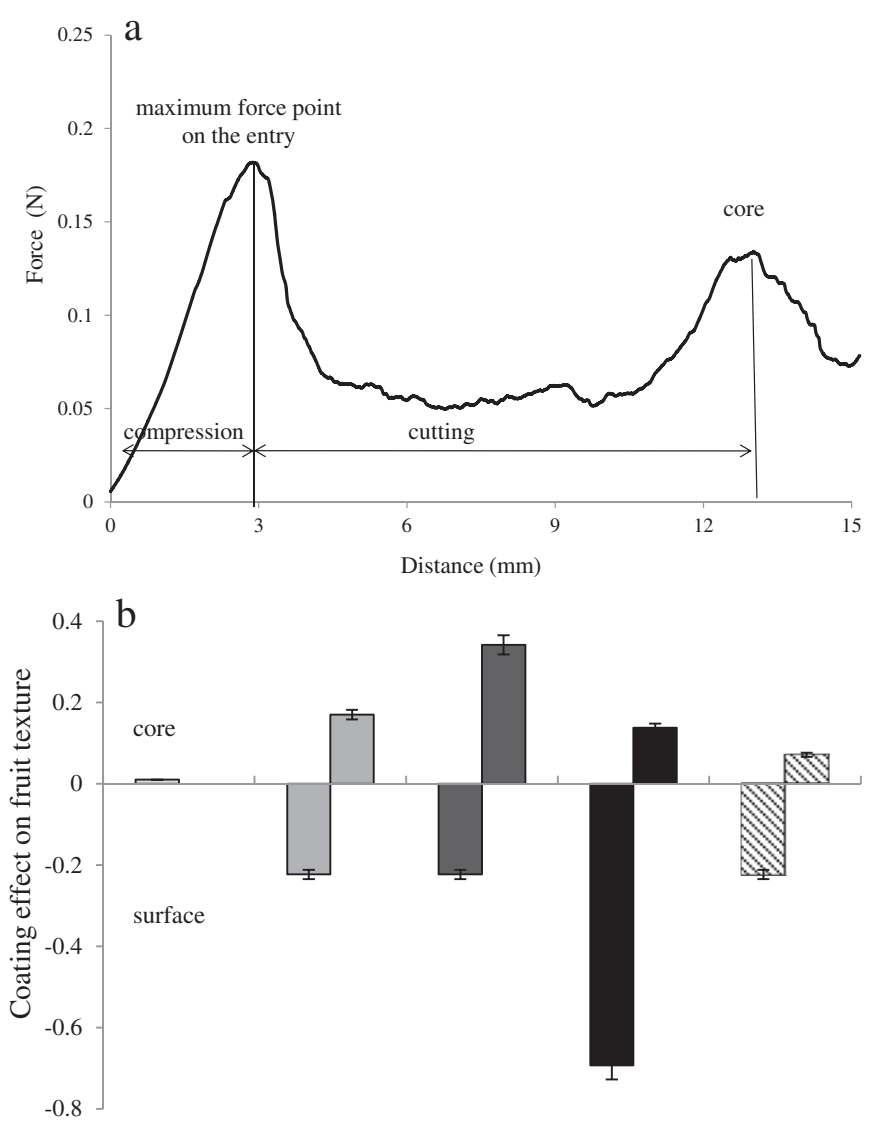

Fig. 6. Force-displacement curve obtained from the cutting test (a) and coating effect on the strawberry texture (b). Negative values indicate softening and positive values hardening compared with fresh strawberry. Error bars represent the standard deviation $(n=6)$. Control (white bars), chitosan (light grey bars), beeswax-chitosanbeeswax (dark grey bars), beeswax-chitosan-TPP-beeswax (black bars) and composite coated samples (patterned bars). 

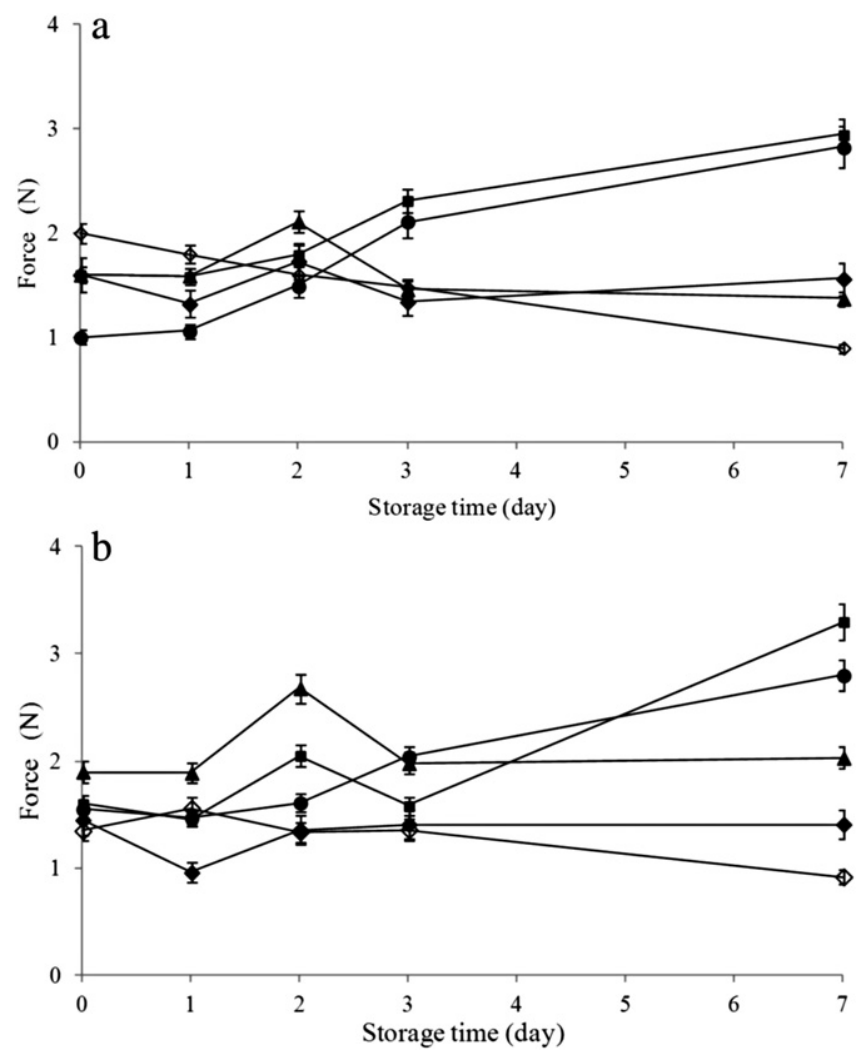

Fig. 7. Effect of the coating on the surface (a) and core (b) firmness of strawberries stored at $20^{\circ} \mathrm{C}$. The vertical bars indicate the standard deviation $(n=6)$. Control (open diamonds, $\diamond$ ), chitosan (full squares, $\mathbf{\square}$ ), beeswax-chitosan-beeswax (full triangles, $\boldsymbol{\Delta}$ ), beeswax-chitosan-TPP-beeswax (full circles, - ) and composite coated samples (full diamonds, $\bullet$ ).

induced slight increase of the firmness, probably due to the increased temperature of the beeswax coating solution. It has been reported that heat treatments could increase the firmness and delay the softening in different fruits (Vicente et al., 2005).

The changes of the strawberry firmness between the control and coated fruits during 7 days of storage at $20^{\circ} \mathrm{C}$ are given in Fig. 7. All samples had similar initial firmness values at $p>0.05$ level as measured by the cutting test. The control or non-coated fruits exhibited liner decrease in the both surface and core firmness over the storage period. These kinds of changes could be attributed to the higher water loss and fungal infection which led to more pronounced tissue senescence and cell wall breakdown. All coating formulations kept the firmness of the whole coated strawberry constant during the storage period. Improvement of the flesh firmness of coated fruits was related to the reduced fruit metabolism (Fig. 4). The beneficial effect of the coating applications on the strawberry texture were reported for coatings prepared from cactus mucilage (Del-Valle, Hernández-Muñoz, Guarda, \& Galotto, 2005); chitosan-oleic acid coatings (Vargas et al., 2006) and chitosan coatings in combination with calcium dips (HernándezMuñoz et al., 2008).

\subsection{Chemical analysis}

The data from the chemical analysis of the control and coated strawberries during storage time are given in Table 4. In all samples, the initial $\mathrm{pH}$ of 4.4 of strawberries decreased during storage, yielding in significant differences at the end of the storage period. Still, there were no significant differences among the $\mathrm{pH}$ values of the variously coated fruits at the end of the storage period. The end $\mathrm{pH}$ values for coated strawberries of $3.7 ; 3.7 ; 3.9$ and 4 for beeswax-chitosan-TPP-beeswax (D), composite (E), chitosan (B) and beeswax-chitosan-beeswax (C) coating, respectively, were still above the average reported values for ripe strawberry of 3.3 (Green, 1971). The results for the organic acids, the second most important component of the strawberry flavor were in agreement with the $\mathrm{pH}$ values. The percentage of the titratabale acidity was between 0.3 and 0.6 for the differently coated samples during the storage period. These values are close to the lowest values mentioned in the literature, between 0.6 and 2.3\% (Montero, Mollá, Esteban, \& López-Andréu, 1996). Titratabale acidity significantly decreased $(p<0.05)$ as a function of the storage time for all coating applications that were studied. The control samples on the other hand, exhibited slightly higher value for the titrable acidity after the 7 th day of storage. The decrease in the titrable acidity indicated the maturity development and was also reported by Garcia et al. (1998) for strawberries coated with starch-based coatings.

The soluble solids content of coated samples remained constant until the third day of storage and showed no significant difference ( $p>0.05$ ) among the treatments. Only the soluble solid content of the control strawberries was higher and differed significantly from the rest of the fruits, caused the considerable loss of water during storage at $20{ }^{\circ} \mathrm{C}$. At the end of the storage four of the samples (control strawberries and composite and three-layer coated fruits) had decreased content of the soluble solids due to the respiration.

Table 4

Soluble solids, $\mathrm{pH}$ value, titratable acidity, maturity index and reducing sugars contents of control (A) and coated strawberries (B-E) stored at $20{ }^{\circ} \mathrm{C}$.

\begin{tabular}{|c|c|c|c|c|c|c|}
\hline & Days & A & B & C & $\mathrm{D}$ & $\mathrm{E}$ \\
\hline \multirow[t]{3}{*}{$\overline{\mathrm{pH}}$} & 0 & $4.4 \pm 0.1^{\mathrm{aA}}$ & $4.4 \pm 0.1^{\mathrm{aA}}$ & $4.4 \pm 0.1^{\mathrm{aA}}$ & $4.4 \pm 0.1^{\mathrm{aA}}$ & $4.4 \pm 0.1^{\mathrm{aA}}$ \\
\hline & 3 & $4.0 \pm 0.1^{\mathrm{bA}}$ & $4.0 \pm 0.1^{\mathrm{bA}}$ & $4.2 \pm 0.1^{\mathrm{aA}}$ & $4.2 \pm 0.1^{\mathrm{aA}}$ & $4.0 \pm 0.1^{\mathrm{abA}}$ \\
\hline & 7 & $3.6 \pm 0.1^{\mathrm{bcA}}$ & $3.9 \pm 0.1^{\mathrm{bA}}$ & $4.0 \pm 0.1^{\mathrm{abA}}$ & $3.7 \pm 0.1^{\mathrm{bA}}$ & $3.7 \pm 0.1^{\mathrm{aA}}$ \\
\hline \multirow[t]{3}{*}{ Titratable acidity (g citric acid/100 g) } & 0 & $0.5 \pm 0.01^{\mathrm{aA}}$ & $0.5 \pm 0.01^{\mathrm{aA}}$ & $0.5 \pm 0.02^{\mathrm{aA}}$ & $0.5 \pm 0.01^{\mathrm{aA}}$ & $0.5 \pm 0.01^{\mathrm{aA}}$ \\
\hline & 3 & $0.6 \pm 0.02^{\mathrm{abA}}$ & $0.4 \pm 0.01^{\mathrm{bB}}$ & $0.4 \pm 0.01^{\mathrm{bB}}$ & $0.4 \pm 0.01^{\mathrm{bC}}$ & $0.5 \pm 0.02^{\mathrm{bC}}$ \\
\hline & 7 & $0.6 \pm 0.02^{\mathrm{bA}}$ & $0.4 \pm 0.01^{\mathrm{bB}}$ & $0.3 \pm 0.01^{\mathrm{cC}}$ & $0.4 \pm 0.01^{\mathrm{cB}}$ & $0.5 \pm 0.02^{\mathrm{bD}}$ \\
\hline \multirow[t]{3}{*}{ Soluble solids ( $\mathrm{g} / 100 \mathrm{~g})$} & 0 & $7.0 \pm 0.8^{\mathrm{aA}}$ & $7.0 \pm 0.7^{\mathrm{aA}}$ & $7.0 \pm 0.6^{\mathrm{aA}}$ & $7.0 \pm 0.8^{\mathrm{aA}}$ & $7.0 \pm 0.2^{\mathrm{aA}}$ \\
\hline & 3 & $7.7 \pm 1.2^{\mathrm{aA}}$ & $7.1 \pm 0.8^{\mathrm{aB}}$ & $6.3 \pm 0.4^{\mathrm{aB}}$ & $6.8 \pm 0.6^{\mathrm{aB}}$ & $6.2 \pm 0.5^{\mathrm{aB}}$ \\
\hline & 7 & $6.5 \pm 0.6^{\mathrm{aA}}$ & $7.5 \pm 0.6^{\mathrm{aB}}$ & $5.0 \pm 0.2^{\mathrm{bC}}$ & $6.3 \pm 0.5^{\mathrm{aA}}$ & $5.4 \pm 0.4^{\mathrm{bC}}$ \\
\hline \multirow[t]{3}{*}{ Reducing sugars $(\mathrm{g} / 100 \mathrm{~g})$} & 0 & $3.5 \pm 0.1^{\mathrm{aA}}$ & $3.5 \pm 0.1^{\mathrm{aA}}$ & $3.5 \pm 0.1^{\mathrm{aA}}$ & $3.5 \pm 0.1^{\mathrm{aA}}$ & $3.5 \pm 0.1^{\mathrm{aA}}$ \\
\hline & 3 & $1.4 \pm 0.1^{\mathrm{bcA}}$ & $1.5 \pm 0.1^{\mathrm{bcAB}}$ & $1.3 \pm 0.1^{\mathrm{bcA}}$ & $1.5 \pm 0.1^{\mathrm{bcAB}}$ & $1.2 \pm 0.1^{\mathrm{cA}}$ \\
\hline & 7 & $1.9 \pm 0.1^{\mathrm{bcA}}$ & $1.5 \pm 0.1^{\mathrm{bcA}}$ & $1.8 \pm 0.1^{\mathrm{bB}}$ & $1.6 \pm 0.1^{\mathrm{bAB}}$ & $1.4 \pm 0.1^{\mathrm{cA}}$ \\
\hline \multirow[t]{3}{*}{ Maturity index ( $\mathrm{Brix} / \%$ acid $)$} & 0 & $14.0 \pm 0.4^{\mathrm{aA}}$ & $14.0 \pm 0.4^{\mathrm{aA}}$ & $14.0 \pm 0.4^{\mathrm{aA}}$ & $14.0 \pm 0.4^{\mathrm{aA}}$ & $14.0 \pm 0.4^{\mathrm{aA}}$ \\
\hline & 3 & $12.4 \pm 0.3^{\mathrm{bA}}$ & $17.6 \pm 0.5^{\mathrm{bB}}$ & $15.8 \pm 0.4^{\mathrm{abA}}$ & $17.0 \pm 0.3^{\mathrm{bA}}$ & $12.4 \pm 0.4^{\mathrm{abA}}$ \\
\hline & 7 & $10.8 \pm 0.3^{\mathrm{aA}}$ & $18.9 \pm 0.6^{\mathrm{cB}}$ & $16.7 \pm 0.5^{\mathrm{bB}}$ & $15.8 \pm 0.3^{\mathrm{cBC}}$ & $10.8 \pm 0.3^{\mathrm{aA}}$ \\
\hline
\end{tabular}

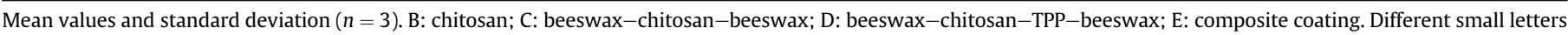

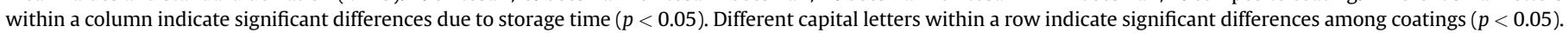


The reducing sugar concentration of the three-layer and composite coated sample was the lowest, suggesting that the incorporation of the beeswax in the coating treatments slowed down the conversion of reducing sugars in the strawberries. Considering that an acceptable strawberry flavor is achieved with a minimum of soluble solids of $7 \%$ and a maximum of titratable acidity of $0.8 \%$, or maturity index above 6 , all the coated fruits were acceptable for consumption due to their much higher maturity index than the average values quoted in the literature (Manning, 1996).

The results demonstrated that the coatings prolonged the shelflife of the strawberries by slowing down the metabolism and delaying their ripening as indicated by the retention of the firmness, color, loss of titratable acidity, total soluble solids content and retarded production of reducing sugars.

\subsection{Sensory analysis}

All attributes were subjected to principal component analysis. The eigenvalues were used to identify the number of principal components to be retained in order to comprehend the data structure. There was a drastic change after the second eigenvalue, meaning that the first two components explained $70 \%$ of the variance of information contained in the sensory data set. The projections of the original variables in the subspace of the principal components are depicted in Fig. 8. It could be seen that the sensory acceptance of the strawberries and the intention to buy them was positively correlated with the luminosity or the visual appearance of the fruits (Fig. 8a). On the other side, they were negatively correlated with the presence of the aftertaste and hence decreased aroma in the samples. The value for the sweetness of the fruits was more distant from both axes and closer to the their center, indicating its low contribution to the discriminating groups and helping us to find out which variables contributed the most to the difference among the groups. From the chemical analysis, it was shown (Fig. 8b) that the total soluble solids as well as the total titratable acidity, were positively correlated with the acceptance of the fruits, while the low $\mathrm{pH}$ and reducing sugars content would have negative impact on the fruit's acceptance. The $L^{*}$ value of the fruit's surface color seemed to have low contribution to the discriminating groups (Fig. 8c). Since the red and vivid color of the strawberries usually came from the chroma and hue values, those were the variables that contributed the most to the difference among the groups. It was shown that the hue and chroma values together with the fruit's firmness were positively correlated with the acceptance, which accompanied the findings from the sensory tests that the acceptance mainly depends on the visual appearance of the strawberries.

Furthermore, the sensory evaluation of the control and coated strawberries was analyzed trough one-way analysis of variance taking into account the effect of the different coating on the quality attributes such as luminosity, aroma, sweetness, aftertaste, overall acceptance and intention to buy (Fig. 9). The judges evaluated the coatings $C$ and $D$ significantly less $(p<0.05)$ luminous or shiny than the rest of the samples. In contrast to the results reported by Han and Gennadios (2005), the composite coating did not reduce the gloss of the strawberries. Chitosan could show astringent taste due to its dissolution in an acidic medium. This astringent taste was detected in sensory evaluations of strawberries carried out on the very day of film application by Deblieguere, Vermeulen, and Debreve (2004) and Vargas et al. (2006). This was not observed in the present study, since the sensory analysis was performed on the third day of storage. The aroma of the samples coated with three-layer coatings ( $C$ and D) was significantly different $(p<0.05)$ when compared to the control fruits and strawberries coated with just chitosan or composite coating. The change of the aroma in the samples $C$ and $D$ was accompanied by the presence of an aftertaste in the same samples, most probably due to the alcoholic solution for the beeswax coating. The panelists detected an untypical alcoholic aroma in the samples coated with the beeswax coating, but did not report any presence of oily aroma. Furthermore, composite coatings, where the lipid component was dissolved in heated chitosan solution did not exhibit any aftertaste or strange aroma. From the results for the overall acceptance and the intention to buy it was evident that the judges showed significant preference for the chitosan and composite coated fruit which obtained mean acceptance scores above 3 on the 6 -point intensity scale. When asked to order
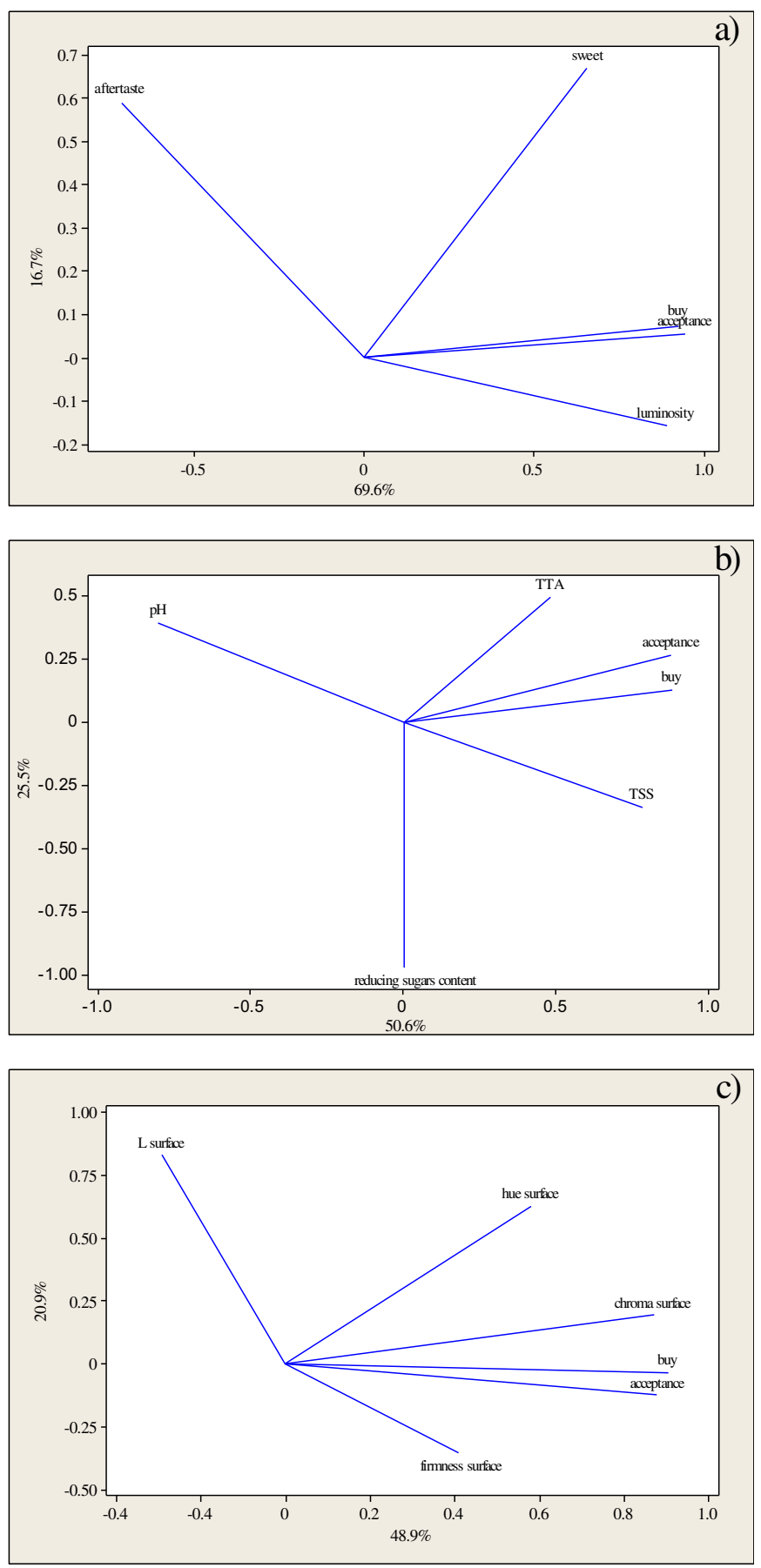

Fig. 8. The loading plots of the first two principal components of the sensory (a), chemical (b) and mechanical (c) variables. 


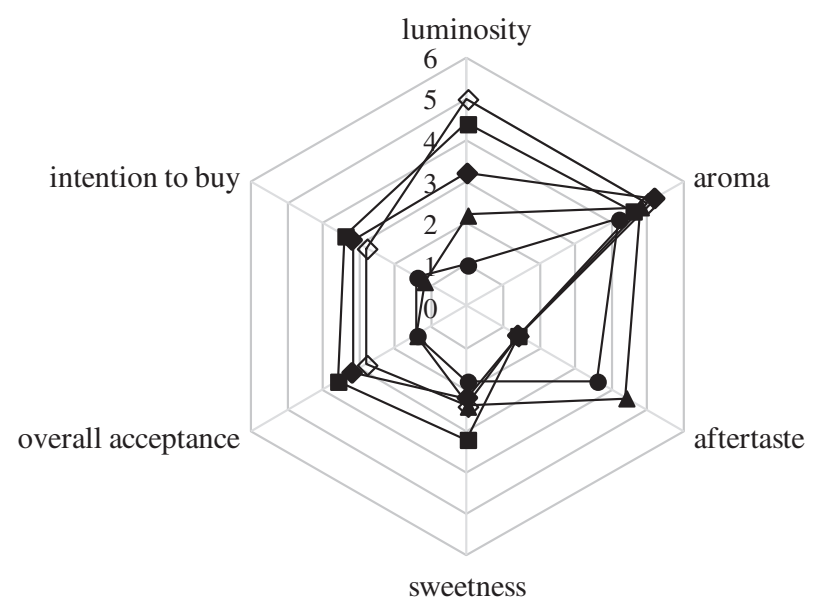

Fig. 9. The average sensory scores of the strawberry fruits. Control (open diamonds, $\diamond$ ), chitosan (full squares, $\mathbf{\square}$ ), beeswax-chitosan-beeswax (full triangles, $\boldsymbol{\Delta}$ ), beeswax-chitosan-TPP-beeswax (full circles, - ) and composite coated samples (full diamonds, $\bullet$ ). The score above 3.5 is acceptable for luminosity, aroma, taste, overall acceptance and intention to buy, while score bellow 3.5 is acceptable for the aftertaste. A 6-point scale was used for the sensory scores.

the fruits according to their intention to buy, the panelists organized the different fruit groups in the following order: $\mathrm{B}>\mathrm{E} \geq \mathrm{A}>\mathrm{D}>\mathrm{C}$.

At the end, a cluster analysis was used to identify the similar groups according to all measured parameters within the strawberry samples. As can be seen from Fig. 10, the first division of the fruit samples is made into two clusters 1 and 2. Cluster 1 grouped together the control and monolayer coated strawberries and it is composed of two subclusters, $1^{\prime}$ and $1^{\prime \prime}$. Subcluster $1^{\prime}$ contained the control strawberries and strawberries coated with composite film, while subcluster $1^{\prime \prime}$ represented the strawberries coated with chitosan film. The three-layer coated strawberries on the other hand, which had separate wax layers in the coating, belonged to the cluster 2 and were distinguished by the significantly lower sensory acceptance of the panel group. Cluster analysis confirmed the sensory analysis results that the chitosan and composite coating could be used to coat strawberries since their taste was not perceptible by the judges and they still enhanced the shelf life of the strawberries compared to the control samples. On the other hand, the judges disliked the appearance and the taste of the three-

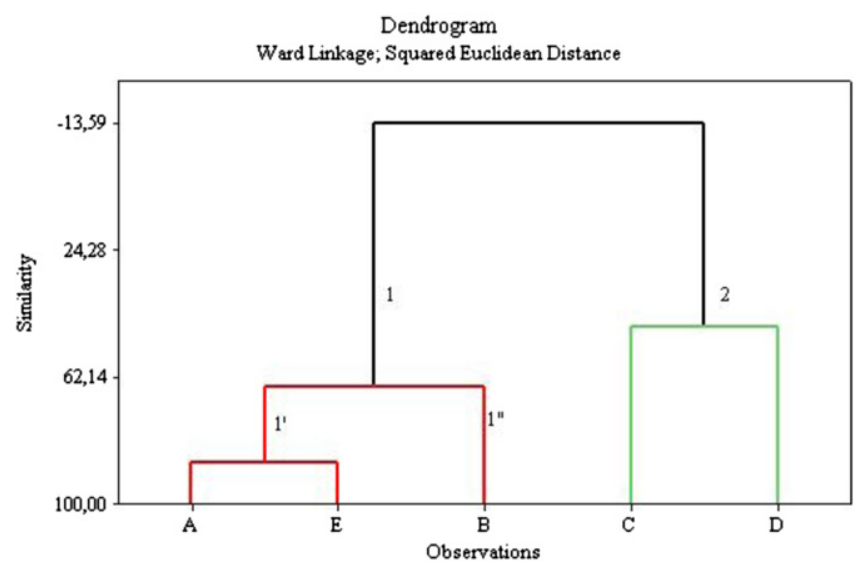

Fig. 10. Dendogram showing clustering of all strawberry samples based on the color, firmness, chemical and sensory analysis of the strawberries. Control (A), chitosan (B) beeswax-chitosan-beeswax (C), beeswax-chitosan-TPP-beeswax (D) and composite (E) coated fruits. layer waxy coatings, even though these coatings were the best for maintaining the quality of the strawberries during the whole storage period. The higher overall acceptance of the coated strawberries by the trained judges was probably due to the lower levels of dehydration and darkening of the coated strawberries.

\section{Conclusion}

The chitosan and composite coatings were transparent, while the three-layer coatings were more mat and slightly white. The chitosan based coatings prolonged the storage period of strawberries for seven days at temperature of $20^{\circ} \mathrm{C}$ and relative humidity of $53 \%$ and slowed down their senescence process compared to uncoated strawberries. The addition of beeswax as separate layer or as a component in the composite coating showed beneficial effect against fungal infection, weight loss reduction, and respiration rate, retention of the firmness and color, as well as retention of the titratable acidity, $\mathrm{pH}$, soluble solids and sugars. The sensory evaluation of the strawberries showed that fruits coated with chitosan $(0.8 \mathrm{~g} / 100 \mathrm{~g})$ and composite coating $(0.8 \mathrm{~g} / 100 \mathrm{~g}$ chitosan and $10 \mathrm{~g} /$ $100 \mathrm{~g}$ beeswax emulsion) had higher overall acceptance and intention to buy. The judges disliked the sensory properties of the three-layer waxy coatings, even though they maintained the best the quality of the strawberries during the storage period.

\section{References}

Alves, V., Costa, N., \& Coelhoso, I. (2010). Barrier properties of biodegradable composite films based on kappa-carrageenan/pectin blends and mica flakes. Carbohydrate Polymers, 79, 269-276.

An, D. S., Park, E., \& Lee, D. S. (2009). Effect of hypobaric packaging on respiration and quality of strawberry and curled lettuce. Postharvest Biology and Technology, $52,78-83$.

ASTM D5229. (2010). Standard test methods for moisture absorption properties and equilibrium conditioning of polymer matrix composite materials. In Annual Book of standards.

ASTM D882-91. (1996). Standard test methods for tensile properties of thin plastic sheeting. In Annual Book of standards.

ASTM E96-80. (1996). Standard test methods for water vapour transmission of materials. In Annual Book of standards.

Atress, A. S. H., El-Mogy, M. M., Aboul-Anean, H. E., \& Alsanius, B. W. (2010). Improving strawberry fruit storability by edible coating as a carrier of thymol or calcium chloride. Journal of Horticultural Science and Ornamental Plants, 2, 88-97.

Campaniello, D., Bevilacqua, A. Sinigaglia, M., \& Corbo, M. R. (2008). Chitosan: antimicrobial activity and potential applications for preserving minimally processed strawberries. Food Microbiology, 25, 992-1000.

Castello, M. L., Fito, P. J., \& Chiralt, A. (2010). Changes in respiration rate and physical properties of strawberries due to osmotic dehydration and storage. Journal of Food Engineering, 97, 64-71.

Debeaufort, F., \& Voilley, A. (1995). Effect of surfactants and drying rate on barrier properties of emulsified edible films. International Journal of Food Science $\mathcal{E}$ Technology, 30, 183-190.

Deblieguere, F., Vermeulen, A., \& Debevere, J. (2004). Chitosan: antimicrobial activity, interactions with food components and applicability as a coating on fruit and vegetables. Food Microbiology, 21, 703-714.

Del-Valle, V., Hernández-Muñoz, P., Guarda, A., \& Galotto, M. J. (2005). Development of a cactus-mucilage edible coating (Opuntia ficus indica) and its application to extend strawberry (Fragaria ananassa) shel-life. Food Chemistry, 91, 751-756.

Fan, Y., Xu, Y., Wang, D., Zhang, L., Sun, J., Sun, L., et al. (2009). Effect of alginate coating combined with yeast antagonist on strawberry (Fragaria $\mathrm{x}$ ananassa) preservation quality. Postharvest Biology and Technology, 53, 84-90.

Garcia, M. A., Martino, M. N., \& Zaritzky, N. E. (1998). Plasticized starch-based coatings to improve strawberry (Fragaria ananassa) quality and stability. Journal of Agricultural and Food Chemistry, 46, 3758-3767.

Garcia, L. C., Pereira, L. M., de Luca Sarantopoulos, C. I. G., \& Hubinger, M. D. (2010). Selection of edible starch coating for minimally processed strawberry. Food and Bioprocess Technology, 3, 834-842.

Green, A. (1971). Soft fruits. In A. C. Hulme (Ed.), The biochemistry of fruits and their products 2 (pp. 375-410). London and New York: Academic Press.

Han, J. H., \& Gennadios, A. (2005). Edible films and coatings: a review. In J. H. Han (Ed.), Innovations in food packaging (pp. 239-262). Amsterdam, NL: Elsevier Academic Press.

Harker, F. R., Redgwell, R. J., Hallett, I. C., Murray, S. H., \& Carter, G. (2000). Physical and mechanical changes in strawberry fruit after high carbon dioxide treatments. Postharvest Biology and Technology, 19, 139-146. 
Hernández-Muñoz, P., Almenar, E., Del Valle, V., Velez, D., \& Gavara, R. (2008). Effect of chitosan coating combined with postharvest calcium treatment on strawberry (Fragaria x ananassa) quality during refrigerated storage. Food Chemistry, $110,428-435$

Hernández-Muñoz, P., Almenar, E., Ocio, M. J., \& Gavara, R. (2006). Effect of calcium dips and chitosan coatings on postharvest life of strawberries (Fragaria $\mathrm{x}$ ananassa). Postharvest Biology and Technology, 39, 247-253.

Koyuncu, M. A., \& Dilmaçünal, T. (2010). Determination of vitamin C and organic acid changes in strawberry by HPLC during cold storage. Notulae Botanica Horti Agrobotanici, 38, 95-98.

Lima, A. M., Cerqueira, M. A., Souza, B. W. S., Santos, E. C. M., Teixeira, J. A., Moreira, R. A., et al. (2010). New edible coatings composed of galactomannans and collagen blends to improve the postharvest quality of fruits-Influence on fruits gas transfer rate. Journal of Food Engineering, 97, 101-109.

Lin, B., Du, Y., Liang, X., Wang, X., \& Yang, J. (2011). Effect of chitosan coating on respiratory behavior and quality of stored litchi under ambient temperature. Journal of Food Engineering, 102, 94-99.

Manning, K. (1996). Soft fruits. In G. B. Seymour (Ed.), Biochemistry of fruit ripening (pp. 347-377). London: Chapman and Hall.

Martin-Polo, M., Mauguin, C., \& Voilley, A. (1992). Hydrophobic films and their efficiency against moisture transfer. 1 . Influence of the film preparation technique. Journal of Agricultural and Food Chemistry, 40, 407-412.

Mayachiew, P., Devahastin, S., Mackey, B. M., \& Niranjan, K. (2010). Effects of drying methods and conditions on antimicrobial activity of edible chitosan films enriched with galangal extract. Food Research International, 43, 125132.

Miller, G. L. (1959). Use of dinitrosalycilic acid reagent for determination of reducing sugars. Analytical Chemistry, 31, 426-428.

Mitra, A., \& Dey, B. (2011). Chitosan microspheres in novel drug delivery systems. Indian Journal of Pharmaceutical Sciences, 73(4), 355-366.

Montero, T. M., Mollá, E. M., Esteban, R. M., \& López-Andréu, F. J. (1996). Quality attributes of strawberry during ripening. Science Horticulturae, 65, 239-250.

Navarro-Tarazaga, M. L., Sothornvit, R., \& Perez-Gago, M. B. (2008). Effect of plasticizer type and amount on hydroxypropyl methylcellulose-beeswax edible film properties and postharvest quality of coated plums (Cv. Angeleno). Journal of Agricultural and Food Chemistry, 56, 9502-9509.

Perdones, A., Sanchez-Gonzalez, L., Chiralt, A., \& Vargas, M. (2012). Effect of chitosan-lemon essential oil coatings on storage-keeping quality of strawberry. Postharvest Biology and Technology, 70, 32-41.

Perkins-Veazie, P. (1995). Growth and ripening of strawberry fruit. Horticultural Reviews, 17, 267-297.

Tanada-Palmu, P. S., \& Grosso, C. R. F. (2005). Effect of edible wheat gluten-based films and coatings on refrigerated strawberry (Fragaria ananassa) quality. Postharvest Biology and Technology, 36, 199-208.

Vargas, M., Albors, A., Chiralt, A., \& González-Martínez, C. (2006). Quality of coldstored strawberries as affected by chitosan-oleic acid edible coatings. Postharvest Biology and Technology, 41, 164-171.

Velickova, E., Tylewicz, U., Dalla Rosa, M., Winkelhausen, E., Kuzmanova, S., \& Gomez Galindo, F. (2011). Effect of vacuum infused cryoprotectants on the freezing tolerance of strawberry tissues. LWT-Food Science and Technology, http://dx.doi.org/10.1016/j.lwt.2011.09.013.

Vicente, A. R., Costa, M. L., Martinez, G. A., Chaves, A. R., \& Civello, P. M. (2005). Effect of heat treatments on cell wall degradation and softening in strawberry fruit. Postharvest Biology and Technology, 38, 213-222.

Vu, K. D., Hollingsworth, R. G., Leroux, E., Salmieri, S., \& Lacroix, M. (2011). Development of edible bioactive coating based on modified chitosan for increasing the shelf life of strawberries. Food Research International, 44, 198-203.

Wong, D., Gastineau, F., Gregorski, K. S., Tillin, S. J., \& Pavlath, A. E. (1992). Chitosanlipid films microstructure and surface energy. Journal of Agricultural and Food Chemistry, 40, 540-544.

Wszelaki, A. L., \& Mitcham, E. J. (2000). Effects of superatmospheric oxygen on strawberry fruit quality and decay. Postharvest Biology and Technology, 20,125-133.

Zhu, S., \& Zhou, J. (2007). Effect of nitric oxide on ethylene production in strawberry fruit during storage. Food Chemistry, 100, 1517-1522.

Zúñiga, G. E., Junqueira-Gonçalves, M. P., Pizarro, M., Contreras, R., Tapia, A., \& Silva, S. (2012). Effect of ionizing energy on extracts of Quillaja saponaria to be used as an antimicrobial agent on irradiated edible coating for fresh strawberries. Radiation Physics and Chemistry, 81, 64-69. 